\title{
Büyük Ruhun Romanını Yazan Adam: Mehmet Akif Ersoy ve İstiklal Marşının Kültürel Kaynakları
}

\begin{abstract}
Ahmet KOÇAK*
Öz

Milletlerin hayatında kimi yazarlar, sanatçılar vardır ki ortaya koydukları eserleriyle yaşadıkları dönemi aşıp, çağlar ötesine seslenmekle kalmazlar, eserleriyle beraber bir bilincin teşekkülünde hayati rol oynarlar. Onlar bir ruhu temsil ederler. O ruhtur ki, asırlar boyu toplumun sinesinde yaşar, toplumun belli değerler etrafında şekillenmesini sağlar ve geleceğe de yön verir. Son asırda yetişmiş millî şairimiz Mehmet Akif Ersoy bunlardan birisidir. O, altı asır üç kıtada hüküm sürmüş bir büyük devletin tarih sahnesinden çekilişine ve onun içinden yeni bir devletin çıkmasına şahitlik etmiş bir büyük şahsiyettir. Mehmet Akif edebiyat tarihlerinde fikirleriyle eserleri arasında benzerlik olduğu belirtilen nadir isimlerden birisidir: "İnanmış adam Akif” daha çocukluğundan itibaren yaşadığı dönemin buhranı içinde kendisini iyi yetiştirmiş, dava ruhuyla büyümüş ve o çizgisini hayatı boyunca da kaybetmemiştir. O bir şair, bir vaiz, bir fikir ve aksiyon adamı, en önemlisi millî şairdir. Mehmet Akif, safhalar anlamına gelen hem şiir kitabının birinci kitabının adı hem de bütün şiirlerinin toplandığı Safahat'ında İstiklal Marşın'da geçen temel kavramların kodlarını verir. $\mathrm{Bu}$ makalede milletleri millet yapan, asil ruhun abide eserini yazan Mehmet Akif Ersoy ve onun kaleme aldığı, ancak kitabına almayarak milletine armağan ettiği İstiklal Marşı'nın kültürel arka planı üzerinde durulacaktır.
\end{abstract}

Anahtar Kelimeler: İstiklal Marşı, Mehmet Akif, kültürel kaynak, Safahat.

\footnotetext{
* Doç. Dr. İstanbul Medeniyet Üniversitesi, Edebiyat Fakültesi, Türk Dili ve Edebiyatı Bölümü, İstanbul, Türkiye. Elmek: kocakahmet70@hotmail.com https://orcid.org/0000-0002-0033-4188.
} 


\title{
Mehmet Akif Ersoy, the Man Who Wrote the Novel of the Great Spirit, and the Cultural Sources of the National Anthem
}

\begin{abstract}
There are some writers and artists in the lives of nations who not only go beyond the period in which they live and address beyond the ages, but they also play an important role in raising consciousness through their works. They represent a soul. It is the spirit that has lived in the heart of society for centuries, allowing society to be shaped around certain values and also guiding the future. One of them is Mehmet Akif Ersoy, our national poet who grew up in the twentieth century. He is a great figure who witnessed the downfall of a great state that ruled over three continents for six centuries, and the emergence of a new state in its place. Mehmet Akif is one of the rare names in the history of literature who have similarities between his ideas and works. "Akif as a man who believes" raised himself well in the crisis of the period he lived in since his childhood, grew up with a cause-oriented spirit, and maintained his style throughout his life. He is a poet, a preacher, a man of ideas and action, and, above all, a national poet. Mehmet Akif, provides the codes for the basic concepts in the National Anthem in his Safahat, which is the title of his first book and the one with collection of all his poems. This article focuses on Mehmet Akif Ersoy, who wrote the monumental work of the noble spirit that made nations a nation, as well as the cultural background of the "National Anthem," which he wrote but did not include in his book and gave to his nation as a gift.
\end{abstract}

Keywords: National Anthem, Mehmet Akif, cultural source, Safahat. 


\section{Giriș}

Geçen asrın ilk çeyreği, Osmanlı Devleti'nden Cumhuriyet'e geçişin yaşandığı, içinde Balkan ve I. Dünya Savaşları'nın ortaya çıktığı, zaman olarak kısa, ancak tezahür eden olaylar ve neticeleri açısından uzun bir dönemi kapsar. Bu dönemde Türk fikir ve siyasi hayatına yön veren önemli isimler yetişmiştir. Topluma yön veren, yaşamları ve eserleriyle geride iz bırakan, bir çığır açan isimlere, ister zirve isim, ister dava insanı, ister abide şahsiyet diyelim genel ifadeyle öncü insan olarak zikredilebilir. Çünkü bu isimler, hayatlarıyla, eserleriyle, düşünceleriyle sadece yaşadıkları dönemi, çağı aydınlatmazlar, nesiller boyu devam edecek bir yolun açılmasına da vesile olurlar. Bir neslin yetişmesine öncülük ederler. Böyle isimlerin pek çok vasıfları vardır: Şairdir, yazardır, fikir insanı, aksiyon ve dava adamı, karakter abidesi, vefa insanı, yardımsever, hamiyet sahibi gibi. Bu vasıfların tamamını üzerinde barındıran gerçek hayattaki yaşamlarıyla düşünceleri bire bir aynı olan "ne söylemişse inanarak söyleyen" nadir insanlar vardır. Bu insanlardan birisi de Mehmet Akif Ersoy'dur. Nurettin Topçu, Mehmet Akif'i anlattı̆̆ kitabında “büyük adam eseri ile hayatını birleştiren adamdır.” tespitini yapar (Topçu, 1993:15).

Mehmet Akif'in pek çok yönünden, özelliğinden bahsedilebilir. Ancak en başta gelen vasfı iyi bir şair ve dolayısıyla, millî şairimiz olmasıdır. Çünkü "büyük şairlerin başlıca farikası, yüz yıllar öncesinden yüzyıllar sonrası için konuşmalarıdır. Edebiyat estetiğinde çok yönlülük veya 'çok değerlilik' denilen ölçü budur. Bunun için onların eserlerinde geleceğin, hatta ebediliğin tohumları gizlidir. Herhangi bir zamanda yazılmış bir eserin asırlara çarpa çarpa bugün de yankılanmasının sebebi budur. Büyük şairlerin kadim çağlardan beri kâhinlere benzetilmesi de bundandır. Onların eserleri geçmiş-bugün-gelecek diye ayrı zaman dilimleri tanımaz." (Emil, 1989: ). 
Mehmet Akif üzerine ilk eserlerden birisini kaleme alan Süleyman Nazif onun hem ruh hâli hem de sanatıyla ilgili şu tespiti yapar: "O, hem tahkiyede harikulâde tasvir kudreti ve hislerinde samimi ve coşkun belagatler gösteren bir şair, hem eşyayı ve vâkıaları ruhlarına ve gizliliklerine işleyen bakışlarla gören bir gözleyicidir.” (Süleyman Nazif, 2016: 95).

Mehmet Akif fikir ve aksiyon insanı olmasının yanında, Türk edebiyatı için de çok önemli bir isimdir. O, geçen asrın başlarında şiirleriyle, yazılarıyla, vaazlarıyla, eserleriyle toplumu aydınlatmaya, yol göstermeye öncülük etmiş ve geride bıraktıklarıyla buna devam eden bir büyük şahsiyettir.

\section{Mehmet Akif'in Fikir Dünyası ve Şiirinin Kaynakları}

On dokuzuncu asrın son çeyreğinde İstanbul Fatih Sarı̈üzel'de dünyaya gelen Mehmet Akif (1873-1936), anne tarafindan Orta Asya, Buhara'dan Tokat'a göç etmiş bir aileden, baba tarafından ise Arnavutluk'un İpek kasabasındandır. Babası Mehmet Tahir Efendi kuvvetli bir medrese tahsili görmüş, devrin din uleması sınıfı içinde imtiyazlı bir yeri olan Fatih Dersiamlarındandır. Mehmet Akif, babasının kendi hayatındaki yerini şiir kitabı 3. Safahat “Hakk'ın Sesleri'nde şöyle ifade eder: "Babam Fatih müderrislerinden İpekli Tahir Efendi merhumdur ki, benim hem babam hem hocamdir. Ne biliyorsam kendisinden öğrendim ${ }^{1}$ (Ersoy, 1988: 184).

Tahir Efendi oğlu Mehmet Akif'i daha çocukluk yıllarında dinî eğitimle yetiştirmeye başlar. Evlerinin bulunduğu muhitte yer alan Fatih Camii'ne çocuklarını sık sık namaza götürür. O, 1908'den sonra yayınladığı ilk şiirlerinden "Fatih Camii'nde" çok sevdiği babasını şöyle hatırlamaktadır:

"Sekiz yaşında kadardım. Babam gelir: 'Bu gece,

Sizinle camie gitsek çocuklar erkence.

1 Mehmet Akif' in bu açıklaması 'Üç beyinsiz kafanın derdine, üç milyon halk/Bak nasıl dolanıyor? Kalk, baba, kabrinden kalk!) ikinci mısranın sonuna konulan dipnotta yer alır. bk, Mehmet Akif Ersoy, Safahat, MÜ. İlahiyat Fakültesi Vakfı Yay. İstanbul 1988, s.184. 
Giderseniz gelin amma namazda işte uslu durun;

Meramınız yaramazlıksa işte ev, oturun!” (Ersoy, 1988: 8).

Şiirin devamında kardeşiyle beraber babasının yanında camiye giden çocuklar, beyaz sarıklı, vücudu zinde, "saç sakal ziyadece ak, mehib yüzlü babası "edeple namaz" kılarken hasırlar üzerinde oynamaya başlarlar. Çocukların huşu ile kılınan namaz aralarında caminin içinde çocuk ruhuyla rahatça oynamalarına, sağa sola koşmalarına babasının hiç ses çıkarmadığı, onlara hiçbir uyarı yapmadığı, bilakis camiye gelip oynamalarından memnun olduğu anlaşılmaktadır.

Âlim ve dindar bir insan olan Tahir Efendi, bulunduğu hocalık mevkiine tamamen kendi gayreti, çalışkanlığıyla gelmiştir. Medrese tahsili ve hocalığı sırasında temizliğe dikkatiyle de Tahir Efendiye "Temiz" sıfatı da eklenmiş, "İpekli Temiz Tahir Efendi” diye anılmaya başlamıştır (Düzdağ, 1988: 4). Mehmet Akif, Safahat'ın başka bölümlerinde konu yine aile şeceresine gelince dedesinin “İpek'in köylüsü, yarı ümmi yarı vahşi bir adam..." olduğunu, dolayısıyla babasının da kendi babasından çok şey öğrenmediğini, kendi gayreti ve çalışkanlığıyla ilim sahibi olduğunu söyler. Sonra da konuyu kendisine getirerek üç satırlık bir ilme sahip se onu babasından aldığını ifade eder:

"Bir şey ögrenmedi elbette o ümmi babadan.

Ne kazanmışsa, bütün, kendi kazanmış, kendi.

Zat-ı devletleri, lakin azıcık çöplendi.

Sen dua et babadan topladiğın mirasa,

Hep onun himmetidir üç satır ilmin varsa

- ̈̈ç satır hem de, Ilahi, ne tükenmez irfan!’”2 (Safahat, s. 326)

İlk bilgileri babasından alan Mehmet Akif, 1878 yılı şubat ayında Fatih’te Emir Buhari mahalle mektebinde eğitime başlar. Buraya iki yıla yakın devam ettikten sonra Fatih İbtidaisine (İlkokul) geçer. Babasından Arapça öğrenmeye de bu y1l başlar (Fergan, 1938: 517).

2 Metinde geçen Safahat'a ait bütün şiirler, Safahat, MÜ. İlahiyat Fakültesi Vakfı Yay., İstanbul 1988 baskısına alınmıştır. Diyanet İşleri Başkanlığı'nın Dijital Safahat'ının Hakkın Sesleri bölümünden alınmıştır. 
Mehmet Akif'in babası Tahir Efendi aynı zamanda İbnülemin Mahmut Kemal'in babası Mühürdar Emin Paşa ailesinin hususi hocalığını yapar. Ailenin başta Ahmet Tevfik ve İbnülemin Mahmut Kemal olmak üzere diğer çocuklarına ders verir. Bu dersler kışın Bakırcılar'daki Emin Paşa Konağı'nda, yazları ise ailenin Kartal Yakacık’ taki köşklerinde yapılır. Tahir Efendi yazları ailesini de buraya taşır ve Mehmet Akif ailenin çocuklarıyla beraber burada derslere devam eder (İnal, 1969: 2288 ).

Fatih İbtidai okulundan sonra Fatih Merkez Rüştiyesine (ortaokul) başlayan Mehmet Akif, aynı yıllarda babasından Arapça öğrenmeye devam eder. Ayrıca Fatih Camii'nde Farsça dersler veren, Gülistan ve Mesnevi okutan Esad Dede'yi de takip eder. Bu yıllarda şiire merak saran Mehmet Akif, şiir kitaplarını okumaya başlar. İlk okuduğu kitaplardan birisinin Fuzuli’nin Leyla ve Mecnun olduğu ifade edilir (Düzdağ, 1988: 5). Babasının talebesi ve kendisinin de ders arkadaşı ve ileri de yakın dostlarından olacak İbnülemin Mahmut Kemal'le birlikle şiirler yazmaya çalışır (Çantay, 1966: 16). Mehmet Akif' in Rüşdiye yıllarında iken Muallakat, Hafız, Sâdi, Mevlana, Fuzuli gibi Doğu edebiyatına ait büyük ve önemli isimleri okuduğu bilinmektedir.

Rüştiye mektebinden sonra Mülkiye'ye geçen Mehmet Akif burada bir y1l okuduktan sonra Baytar Mektebi'ne geçer. Ahırkapı'da açılan okul daha sonra Halkalı'ya taşınmış ve Mehmet Akif de burada yatılı kalmışıtır. Baytar Mektebi'nin çoğu doktor ve dindar kimseler olan hocalarından çok şey öğrenmiş, özellikle son iki senesinde şiirle daha çok meşgul olmuştur. ${ }^{3}$ Baytar Mektebi'nde iken Batı edebiyatına merak sarmış, Victor Hugo, Erneste Renan, Anatole France, Alfrede de Musset, Lamartine, Rousseau, Polanyal1 Sienkiewicz (Franszicasından), Alphonse Daudet, Emile Zola, Dumas Fills severek okuduğu yazarlardır.

Mehmet Akif' in makale ve hatıra notlarından başka yazarları da severek okuduğu ya da takdir ettiği anlaşılmaktadır. Süleyman Çelebi, Baki, Nefi,

3 Mehmet Akif, bu yıllarda yazdıklarını daha sonra imha etmiş, çeşitli yerlerde kalan şiirlerini dostları ve araştırmacılar Safahat'a girmeyen şiirlerini ortaya çıkarmaya çalışmışlardır. bk. Fevziye Abdullah Tansel, Mehmet Akif, Hayatı ve Eserleri, hz. Abdullah Uçman, Ötüken Yay. 4. Basım, İstanbul s. 229-262. 
Nedim, Şeyhülislam Yahya, Şeyh Galip, Akif Paşa, Hersekli Arif Hikmet, Şinasi, Ziya Paşa, Namık Kemal, Recaizade Mahmut Ekrem, Osman Şems, Muallim Cudi, Abdülhak Hamit, Eşref ve yakın çevresinden Faruk Nafiz, Midhat Cemal de severek okuduğu ve takdir ettiği isimlerdir. Yine Arap, Fars ve Hint şairlerinden İbni Farız, Feyz-i Hindi, Nabga, Mütenebbi, Ebu Temmam, Buhturi, Ebu Firas, Muhammed İkbal şairin okuduğu isimler arasında yer alır.

Mehmet Akif, Türk fikir hayatında siyasi fikir akımlarının kendi kalıpları içerisinde şekillenmeye başladığı İkinci Meşrutiyet yıllarında, yerli kültür ve değerlere bağlı kalarak Osmanlı Devleti'nin ayakta kalmasının "İttihad-1 İslam” düşüncesi etrafında toplanmak olarak gören ve bunu savunan önemli isimlerdendir. Mehmet Akif, daha önce Cemaleddin Afgani (1839-1897) ile onun öğrencisi Misırlı Muhammed Abduh'un (1849-1905) fikirlerinden ve yazılarından istifade etmiş, bütün Müslümanların uyanarak istiklallerini elde etmeleri için birlik olmalarını gerektiğini sürekli vurgulamıştır. O, daha çok maarif ve ıslahat yoluyla İslam dünyasının kalkınmasını telkin eden Abduh'tan etkilenmiş ve onun bazı yazılarını tercüme ederek, Siratımüstakim' de yayımlamıştır (Düzdağ, 2014:13)

Mehmet Akif, Fars edebiyatından Sadi'yi de çok sevdiği, hatta Sadi ismini mahlas olarak kullandığı bilinmektedir. Maarif mecmuasının MayısHaziran 1895 tarihli sayılarında Sadi imzasıyla yazıları çıkmıştır (Tansel, 1979: 23-24). Yine Servet-i Fünun dergisinin Kasım-Aralık 1898'de çıkan sayılarında yayımlanan Şeyh Sadi'den yaptığı mensur ve manzum tercümeleri de vardır (Düzdăg, 1988: 15).

Mehmet Akif, 1900-1908 yılları arasında devrin siyasi ortamının da uygun olmaması nedeniyle fazla şiir yazmamıştır. Ancak bundan önce Servet-i Fünûn şiirinden Cenap Şahabeddin ve Tevfik Fikret'i -onlara katılmayaraktakdir ettiği bilinmektedir (Okay, 2011: 175-176; Okay, 2015: 82-83.)

Mehmet Akif'in ilk şiir denemelerinin eski tarz üzere olduğu, gazeller yazdığı bilinmektedir. 1893 yılında Hazine-i Fünun'da yedi beyitlik oldukça sade sayılabilecek bir dille ilk gazeli yayımlanır. Gazelin ilk beyti şu şekildedir: 
"Allah'ı seversen nazarımdan güzer etme

Müştakını başın için olsun heder etme!"4

Okulu bitirdikten sonra memuriyete başlayan Mehmet Akif' in 1894 yılı başlarında denk gelen Ramazan ayında İstanbul Süleymaniye'deki Kirazlı Mescid'inde mukabele okuduğu, dost evlerinde teravih namazı kıldırdığı bilinmektedir. Ayrıca onun sekiz on yaşlarında Kur'an hıfzetmeye başladığı ve daha sonra tamamladığı ve iyi bir hafız olduğu aktarılır (Fergan, 1939: 220-221).

Stratımüstakim yayın hayatına başlamadan önce Mehmet Akif, Orman ve Maden Nezaretine bağlı Umur-1 Baytariye Dairesi'nde görevli bir memurdur. Aynı yıllarda Çiftçilik makinist Mektebi’nde Kitabet-i Resmiye (Kompozisyon) muallimliği de yapmıştır. Daire çıkışı Direklerarası'ndaki İsmail Ağa kahvehanesinde yakın dostlarıyla sohbetler ettiği, şiirler okuyarak vakit geçirdiği bilinmektedir.

Mehmet Akif' in asıl topluma mal olmasını sağlayan şüphesiz 27 Ağustos 1908 yılında yayın hayatına başlayan Sıratımüstakim dergisidir. Ebulüla Mardin (1881-1957) ve Eşref Edip (1883-1971)'in öncülüğünde çıkan derginin başyazarı Mehmet Akif'tir. Onun neredeyse bütün şiir ve yazıları burada yayımlanmıştır (Koçak, 2021, 108-112).

24 Kasım 1908'de Dârülfünûn Edebiyat şubesine "Edebiyat-1 Osmaniye" muallimi olarak tayin edilir. Buradaki diğer hocalar, arasında Ahmet Midhat Efendi, Ahmet Naim, İzmirli İsmail Hakkı, Namık Kemalzâde Ali Ekrem, Tevfik Fikret, Şehbenderzâde Filibeli Ahmet Hilmi gibi isimler de vardır (Bilgegil, 1980: 408).

Mehmet Akif'in her ne kadar ilk çalışmaları Sıratımüstakim'de çıkmaya başlamışsa da daha önceleri de şiirler yayımladığı bilinmektedir (Okay, 2015: 83-85). Ancak derginin yayın hayatına girmesiyle Akif' in geniş bir İslam coğrafyasında adı kısa sürede duyulmuştur. Akif'in ilk şöhrete ulaştı̆̆ı yıllar da 1908 'den sonra dergide şiirlerinin yayınlamaya başlamasıyla olmuştur. $\mathrm{Bu}$ 
devir aynı zamanda büyük kargaşaların ortaya çıktığı ve farklı bölgelerde her geçen gün sorunların arttığı yıllardır. Aynı zamanda herkesin kendi hacminde devleti kurtarma formülleri ortaya attığı, en doğrusunun kendi görüşü olduğuna inandığ 1 y1llara da girildiği dönemdir. Mehmet Akif ilk Safahat'ta toplumun bu meselelerini şiirlerinde açıç̧a dile getirir. Orhan Okay’ın ifadesiyle ilk Safahat, “ictimai bir romanın yarım bırakılmış parçaları gibidir.” (Okay, 2015: 37).

Akif Stratımüstakim'de yayımlanan ve Safahat'ın ilk bölümüne aldığ1 şiirlerde İstanbul'un kenar mahalleleri, aile geçimsizlikleri, yoksulluk, mahalle kahvesinde konuşulan günlük konular, şehrin fiziki manzarası, bakımsızlığg1, dilenciler, öksüz kalmış çocuklar, eşini kaybeden ya da sokakta arayan kadınlar, ezilen dayak yiyen kadınlar onun şiirlerinin gerçek karakterlerini oluşturur. "Küfe, Mehyane, Hasır, Mezarlık, Bayram, Selma, Seyfi Baba, Kör Neyzen, İstibdat, Mahalle Kahvesi, Köse İmam, Koca Kar1 ile Ömer” gibi hikâyelerin merkezinde yukarda bahsi geçen konular vardır.

Akif'in bu dönemdeki düşüncelerini Köse İmam'ın ağzından dinleriz:

“Üç sınıf halka içim parçalanır!

İhtiyarlar, karılar, bir de küçükler; bunlar

Merhamet görmeli, yüz görmeli insanlardan;

Yoksa, insanliğı bilmem nasıl anlar insan?" (Safahat, s. 116).

Sıratımüstakim mecmuasında Mehmet Akif, şiirlerinin yanında nesir türünde kaleme aldığ ve ümmetin ortak sıkıntılarına dikkat çekmeye gayret etmiştir.

1912 yılında derginin iki kurucusundan biri olan Mardinizâde Ebülula'nın dergiden ayrılması ve yoluna Serezli Hafız Eşref Edip'in devam etmesi, daha sonra da Sebilürreşad adını almasıyla Akif'in buradaki yazıları da yoğunlaşır. Mecmuanın isim değişikliğinden sonra muhtevasında da değişikliğe kısmen gidilir. Derginin yazarlarından Kazanlı Halim Sabit (Şibay)'in önerisini derginin tefsirle ilgili kısmı Mehmet Akif'e verilmiştir (Mertoğlu, 2011: 206). Hatta Halim Sabit' in önerisi bu ilmin kaideleri ve usulüyle fazlaca 
iştigal etmediği gerekçesiyle Mehmet Akif kabul etmek istemez. Ancak Halim Sabit, "Daha iyi ya! Biz de öyle istiyoruz. Kavâid ve nakliyattan ziyade doğrudan doğruya Kur'an'dan anladığınızı, duyduğunuzu yazınız." talebiyle onu ikna eder. Mehmet Akif, Sebilürreşad'da dinin ana kaynağı Kur'an ve onun açıklaması olan tefsir konularında yazılar kaleme alır (Fergan, 1939: 27-28). Mehmet Akif'in dini muhtevalı yazılarında dile getirdiği temel düşünce, İslam dünyasının içinde bulunduğu sorunlara dikkat çekmek, felahın/kurtuluşun ittihatta/birleşmede olduğudur. Özellikle II. Meşrutiyet sonrası ortaya çıkan ve hızla yaygınlaşan asabiyet meselesine ittihadı yok edeceği düşüncesiyle Kur'an'dan referanslar getirerek karşı çıkar ve şunları ifade eder:

"Müslümanlık ırk, renk, lisan, muhit, iklim itibariyle birbirini büsbütün yabancı unsurları aynı millîyet altında mezceden yegâne rabıta iken, hele biz Osmanlılar için dünyada bu rabıtaya dört el ile sarılmaktan başka selamet yolu yokken, şu son senelerde meydana çıkardığımız kavmiyet, asabiyet gürültülerine şaşmak elden gelmez! Bu kadar hükümât-1 İslamiye hep tefrika yüzünden mahvoldu; hem de birçoğu gözümüzün önünde kaynayıp gitti de biz hâlâ intibaha gelmiyoruz; hâlâ milleti namütenahi parçalara ayıracak bir siyaset güdüyoruz.” (Mehmet Akif, 1912: 62)

Yine Akif ittihadın önemiyle ilgili Kur'an'dan Enfâl suresinden ${ }^{5}$ örnekler vererek şunları ifade eder:

"Yaşamak isteyen millet için ittihadın lüzumu bedihiyyat-1 evveliyedendir. Öyle efradı birbirine kaynamış, heyet-i mecmuası bir bünyân-1 mersus vücuda getirmiş olan cemaatler düşmanın topuyla, tüfengiyle kolay kolay devrilmezler. 'kale içinden fetholunur' sözü ne büyük bir hakikattir. Müslümanlar için bu hakikatten gafil olacak zaman değildir. Hariçteki düşmanı bırakıp da dâhilde birbiriyle uğraşmasınlar." (Mehmet Akif, 1912: 233-234).

Mehmet Akif, Müslümanların içinde bulunduğu dağınık ve perişan halinin temel sebeplerinden birisinin Kur'an'ın hakkıyla anlaşılmamasına ve dini gerçek hayata yansıtamamaya bağlar. Çünkü dünya ve ahiret dengesini

5 "Allah'a ve onun Resulüne itaat edin, birbirinizle çekişmeyin. Sonra içinize korku düşer ve kuvvetiniz elden gider." Enfâl 8/46. 
en güzel şekilde bir esasa bağlamış olan Kur'an hakkıyla anlaşılmış, yaşanmış olsayd1, Müslümanların başına bu yaşanan uğursuzluklar gelmemiş olacaktı. Konuyla ilgili şöyle der:

"Ey mâşer-i Müslümîn, evâir-i ilâhiyeyi dinlemekte biraz daha devam ederseniz büsbütün mahvolursunuz. Allah size 'ilim öğrenin, kuvvet hazırlayın, çalışın, adaleti düstur ittihaz edin, birbirinize muavenette bulunun, hakkı tanıyın, tefrikadan sakının' dedikçe siz bilakis cehle revaç verdiniz; meskenete düştünüz; atalete kapıldınız; zulmü adet edindiniz; birbirinizin gözünü oymaya kalkıştınız; haktan yüz çevirdiniz; namütenahi fırkalara ayrıldınız... Artık bu tuttuğunuz yolu bırakınız. Çünkü o sizi uçurumuna doğru götürüyor. Şeriatın gösterdiği şahrâh-1 felahı tutunuz. Zira sizi kurtaracak ancak odur.” (Mehmet Akif, 1912: 390).

Mehmet Akif, Müslümanların uyuşuk ve bedbinliğini eleştirir ve onları çok çalışmaya sevk eder. Yakın dostu Midhat Cemal'in "Bir dağ silsilesini gezer gibi her seferinde bir başka zirvesini gördüğüm adam..." (Kuntay, 1939: 43) dediği Mehmet Akif'in pek çok yönü üzerinde müstakil bölümler açllabilir.

Mehmet Akif'in Safahat şiir kitabının ikincisi Süleymaniye Kürsüsünde 1912 yılında yayımlanır. Şairin "Kardeşim Fatin Hoca'ya" ibaresiyle Fatin Gökmen'e ithaf ettiği 1002 mısralık tek ve uzun manzumede, eserin başında Galata Köprüsü'nden Yeni Cami'ye doğru gidilir. Haliç'in yosunlu suları ve yolları Mehmet Akif'in nükteli üslubu ile anlatılırken daha sonra Yeni Cami ve Süleymaniye Camii sanatkârane şekilde aktarılır. Cami'nin içine kürsüde aslen Türkistanlı olan bir vaiz hararetli şekilde vaaz etmektedir. Bütün Türk ve İslam dünyasını dolaştığını ifade eden vaiz aslında zaman zaman İstanbul'a da gelmiş olan, Mehmet Akif'in yakın arkadaşlarından Özbekistanlı bir Türk olan Abdürreşit İbrahim Efendi'dir. Vaazda İslam âlemindeki çöküşün ana sebeplerinden birisinin İslam'ın ana kaynaklarından uzaklaşmak olduğu ve şairin İslam ideali gibi fikirleri dile getirilir. Vaazda, Müslümanların Avrupa’ya "fen getirin" diye gönderdiği gençlerin Batı kültürü alarak ve kendisine yabancılaşarak döndükleri, Meşrutiyetin ilanıyla coşkuya kapılan halkın hürriyeti yanlış anlaması gibi konular dile getirilir (Okay, 1988: 40). 
Balkan Savaşlarının başladığ 1912 yılı, beş asırdan fazla Rumeli coğrafyasına akın ederek göç eden Müslüman Türk insanının en büyük felaketi yaşadığ 1 dönemlerden birisidir. Mehmet Akif, bu y1llarda yazdığ şiirleri Safahat'ın üçüncü kitabı olan "Hakk'ın Sesleri”"nde toplamıştır. On şiirin yer aldığı kitapta sekiz şiir Kur'an'dan alınan ayetlerin yorumu, bir şiir hadis yorumu ve son şiir ise "Pek Hazin Bir Mevlid Gecesi" başlı̆̆ını taşır. Balkan Harbi'nin getirdiği yıkım günlerinde Beyazıt, Fatih ve Süleymaniye camilerinde vaazlar eder (Düzdağ, 1988: 63). Yaşanan bütün acıları trajik bir şekilde dile getiren şair, içe dönük düşüncelerini şu mısralarla dile getirir:

"Gitme ey yolcu, beraber oturup ăglaşalım:

Elemim bir yüreğin kârl değil, paylaşalım..

Ne yapıp ye simi kahreyliyeyim, bilmem ki?

Öyle dehşetli muhitimde dönen matem ki!...

Ah! Karşımda vatan nâmına bir kabristan." (Safahat, s. 182).

Bir yıl sonra tek bir manzumeden oluşan (1914) dördüncü Kitap "Fatih Kürsüsünde" yayımlanır. Yine Galata Köprüsü üzerinde buluşan iki arkadaş Eminönü doğru yürürler. Yine şairin nükteli üslubuyla iki arkadaş etrafinda gördüklerini, dinî, siyasi bir takım konuşmalar yaparlar. Nitekim Fatih Camii'ne gelen iki arkadaş kürsüde vaizin çalışma hakkında konuşmasını dinleme başlarlar. Vaiz konuşmasının içinde ara ara (üç kez) şu mısraları tekrar eder:

"Bekayl hak taniyan sa'yi bir vazife bilir;

Çalış, çalış ki beka, sa'y olursa hakkedilir." (Safahat, s. 220, 226-227).

Mehmet Akif, 1914 yılında iki ay sürecek Misır seyahati sırasında Peygamber şehri Medine'yi de ziyaret eder ve burada duyduğu gönül coşkusunu "Necid Çöllerinden Medine'ye" şiirinde dile getirir. Aynı yılın sonlarında devlet tarafından Berlin'e gönderilen Mehmet Akif, 1915 yılında da görevli olarak Arabistan'in Necid bölgesine seyahat eder. Bu seyahatlerin sonucunda "Berlin Hatıraları"; "El-Uksurda" ve "Necid Çöllerinden Medine'ye" gibi Türk şiiri için müstesna manzumeler ortaya çıkar. 
Mehmet Akif'in Safahat'ın beşinci kitabı olarak 1917 yılında basılan eseri "Hatıralar"dır. Yukarda da ifade edildiği gibi, on manzumenin yer aldığ eserde, dördü ayet, ikisi de hadislerin geniş yorumuna dayanır. Ağırlıklı olarak Balkan ve Birinci Dünya Savaşı'nın getirdiği problemler dile getirilir. (Okay, 1988: 41-42).

Mehmet Akif, 1918 yılında dönemin tanınmış İslam âlimlerinin de yer aldığı İstanbul'da kurulan Dârü'l-Hikmet-i İslamiye heyeti arasına dâhil olmuş ve başkâtip olarak tayin edilmiştir. (Düzdağ, 1988: 63).

Millî Mücadele y1llarının hemen öncesinde Mehmet Akif'in Gölgeler kitabında Eylül 1919' da "Şark”' şiirinde çizdiği tablo sadece Osmanlı coğrafyasını değil, bütün İslam âleminin içinde bulunduğu durumu bütün çıplakl1ğyla ortaya koyar:

“Ne gördün, Şark’ l çok gezdin?” diyorlar: Gördüğ̈̈m;

$$
\text { Yer yer, }
$$

Harâb iller; serilmiş hânümanlar; başsız ümmetler;

Yıkılmış köprüler; çökmüş kanallar; yolcusuz yollar;

Buruşmuş çehreler; tersiz alınlar; işlemez kollar;

Bükülmüş beller; incelmiş boyunlar; kaynamaz kanlar;

\footnotetext{
6 Safahat'ta “Şark” şiirinin devamında yer alan ve Şair Eşref'e ithafıyla yayımlanan "Kişi Hissettiği Nispette Yaşar " başlıklı șiir Sebilürreşad dergisinde 19 Eylül 1334 (1918) tarihli 370. sayısında yayımlanır. Bu şiirin ilk neșri "Kiși Hissettiği Nisbette Yaşar" başlığını taşır. Aynı duygu ve düşünceler benzer mısralarla tekrar edilir.

"Asırlardır ki "insâniyyet"in olmuş da mahkûmu,

Astrlar var ki, İslâm'in hederdir hûn-i mazlumu..

"Ne gördün, Şark’ı hep gezdin?” deyip sor. Gördüğ̈̈m: Yer yer

Yıkılmış hânümanlar; devrilip gitmiş hükümetler;

Serâb olmuş kanallar; dümdüz olmuş burç ü bârûlar;

Dökülmüş abrûlar; habsedilmiş zinde bâzular;

Bükülmüş beller: incelmiş boyunlar: coşmayan kanlar;

Düşünmez başla; aldırmaz yürekler; pasll vicdanlar;

Kasap görmüş koyundan beş beter yllgin cemâ'atler;

Tezellüller, tazarru'lar, esaretler, şenâ`atler;

Örümcek bağlamış tütmez ocaklar; yanmış omanlar;

Ekinsiz tarlalar; ot basmış evler; küflü hamanlar;

Cemâ'atsiz imamlar; kirli yüzler: secdesiz başlar,

"Gaza" nâmıyle dindaş öldüren bîçâre dindaşlar,

Ipıssız âşiyanlar; kimsesiz köyler; çökük damlar;

Mesâisiz sabahlar; fikr-i ferdâ bilmez akşamlar!...

Geçerken ă̆ladım geçtim, dururken ağladım durdum;

Bütün, bunlardl, zîrâ, gezdiğim âlemde meşhûdum.

Mezâristan kesilmiş rehgüzârım hüzn-i dûrâdûr... (Safahat, s. 414-415).
} 
Düşünmez başlar; aldırmaz yürekler; paslı vicdanlar;

Tegallübler, esâretler; tehakkümler, mezelletler;

Riyâlar; türlü iğrenç ibtilâlar, türlü illetler;

Örümcek bağlamış, tütmez ocaklar; yanmış ormanlar;

Ekinsiz tarlalar; ot basmıs evler; küflü harmanlar;

Cemaatsiz imamlar; kirli yüzler; secdesiz başlar;

"Gazâ" nâmıyle dindaş öldüren bîçâre dindaşlar;

Ipıssız âşiyanlar; kimsesiz köyler; çökük damlar;

Emek mahrûmu günler; fikr-i ferdâ bilmez akşamlar!.

Geçerken, ağladım geçtim; dururken, ağladım durdum;

Duyan yok, ses veren yok, bin perişan yurda başvurdum." (Safahat, s. 313).

Vatan toprakları işgale uğrayınca ilk harekete geçen isimlerden birisi de büyük şair Mehmet Akif'tir. O, yakın dostu Eşref Edip'le beraber 1920 y1lı başında hemen Balıkesir'e hareket ederek burada Zagnoş Paşa Camii'nde Cuma günü kürsüye çıkarak vaaz verir, halkı birlik olmaya ve Millî Mücadele etrafında toplanmaya davet eder. Nisan ayında da oğlu Emin'i de yanına alarak Millî Mücadele'nin merkezi Ankara'ya hareket etmiştir. Ankara'ya geldikten sonra Hacı Bayram-1 Veli Camii'nden başlayarak halkı aydınlatmaya, mücadeleye davet etmiştir. Burdur mebusu olarak meclise katılan şair, Eskişehir, Burdur, Sandıklı, Dinar, Afyon, Antalya, Konya, Kastamonu gibi şehir ve kasabaları dolaşmıştır (Düzdağ, 1988: 63).

Ankara'da Erkan-1 Harbiye'nin talebi ile Millî Eğitim Bakanlığı tarafindan 1920 yılı sonlarında ilan edilen "İstiklal Marşı” yarışmasına, içinde milletvekillerinin de yer aldığ yedi yüzden fazla şiir katılmıştır (Ayvazoğlu, 1986, 29-33). Millî Eğitim Bakanı Hamdullah Suphi’nin özel gayretiyle Mehmet Akif'e yazdırılan İstiklal Marşı, mecliste 12 Mart 1921 yılında resmen kabul edilmiştir. 


\section{Mehmet Akif'in Kültürel Birikiminin İstiklal Marşı'na}

\section{Yansıması}

Büyük milletler tarihte zor durumda kaldıkları zaman oradan çıkmasını bilen, büyük kahramanlara sahiptirler. Birinci Dünya Savaşı sonunda Anadolu'nun çeşitli bölgeleri işgale uğramış, adeta ülkenin her tarafını karabulutlar basmıştır. Ümit ışı̆̆ının sönmeye yüz tuttuğu bir zamanda Anadolu'nun bağrından doğan Millî Mücadele ruhu, asırlarca hür yaşamış bir milleti, yine ebediyen hür ve bağımsız yaşayacağı bir ülkeye kavuşturmuştur. Bursa'nın işgal edildiği, düşmanın top seslerinin Ankara'dan duyulabilecek kadar yaklaştığı dönemde, hiç kimse de bir ümitsizlik, yese düşme olmamış ve tarihte çok az millete nasip olan bir büyük zafer kazanılmıştır. İşte memleketin böyle zor günlerinde Ankara'da açılan Millî Meclis'te Mehmet Akif tarafından "Kahraman Orduya" ithafiyla yazılan millî marş kabul edilir. Mehmet Akif tarafindan Türk milletinin ortak duygu ve düşüncelerini en şümullü ve veciz şekilde ifade eden İstiklal Marşı, mecliste üç defa ayakta alkışlar arasında ve gözyaşları içinde okunmuş ve kabul edilmiştir (Ayvazoğlu, 1986: 38-49).

Orhan Okay'ın ifadesiyle, “İstiklal Marşı' gerek nazım tekniği gerekse muhteva bakımından herhangi bir millî marş güftesinin çok ilerisinde Türk edebiyatının en güzel lirik - hamasi şiirlerindendir." (Okay, 2001: 355). Mehmet Akif, İstiklal Marşı'nda kendisini milletin yerine koymuş, âdeta onların adına konuşmuştur (Yıldırım, 2007: 247). Dolayısıyla marşta geçen bütün "ben" ifadelerini bütün bir millet konuşuyor gibi algılamak gerekir. Onun sadece "Kahraman Orduya" ithaf ettiği marşta değil, Safahat' ın bütün bölümlerinde dile getirdiği millet özelliğini Ömer Rıza Doğrul şöyle aktarır: "Mehmet Akif' in düşündüğü ve yaşatmak istediği millet ise atalet bataklığını kurutmuş, ilim muhitine ve fen diyarına atılmış, sanayie sarılmış, ticaretini yaymış, hür ve temiz vicdanlı bir millettir (Doğrul, 1944: XXXIV).

İstiklal Marşı, "Korkma, sönmez bu şafaklarda yüzen al sancak;" dizesiyle başlar. Neden "Korkma” ile başladığını anlamak için marşın yazıldığı dönemi 
ve içinde bulunulan zamanı bilmek gerekir. Çünkü İstiklal Marşı'nın yazıldığı dönemde Mehmet Akif ve çağdaşları, çökmekte olan bir imparatorluğun son günlerini ve bir avuç inanmış insanın önderliğinde Ankara'da etrafına toplanan halkla beraber yeni bir ümit ışı̆̆ının doğduğu yılları yaşamışlardır. İçinde yaşanılan zamanda memleketin her tarafindan acı, gözyaşı ve felaket haberleri gelmektedir (Ayvazoğlu, 2006: 161). İşte böyle bir ortamda şiirini yazmaya başlayan Mehmet Akif, adeta istiğrak hâlindedir ve evde, sokakta, Meclis'te, camide, uyurken, yürürken hep İstiklal Marşı'nın mısralarını kurmakla meşguldür (Çağbayır, 2009: 333). Vatan topraklarının çeşitli bölgelerinin işgale uğradığı günlerde çeşitli şehirlerde akil insanlar, din adamları halkı düşmana karşı birlik olmaya, vatan topraklarını savunmaya çağırmıştır. Buralarda da öncelikle korkuya kapılıp, dağılmama salık verilmiştir.?

Mehmet Akif'in şiir üslubuna "Korkma!" şeklinde hitapla başlaması ilk defa değildir. Nitekim Birinci Dünya Savaşı'nın en önemli cephelerinden birisi olan ve tarihe altın harflerle yazılan Çanakkale'de kahramanca çarpışan askerleri anlatırken şöyle seslenir:

“-Korkma!

Cehennem olsa gelen, göğsümüzde söndürürüz;

Bu yol ki Hak yoludur, dönme bilmeyiz, yürürüz!

Düşer mi tek taşı, sandın, harim-i nâmusun?

Meğer ki harbe giren son nefer şehîd olsun.

Şu karşımızdaki mahşer kudursa, çıldırsa;

Denizler ordu, bulutlar donanma yağdırsa;

Bu altımızdaki yerden bütün yanardağlar,

Aşıp da kaplasa afakı bir kızıl sârsar;

Değil mi cephemizin sinesinde iman bir,

\footnotetext{
7 Nurullah Çetin, 1919 yılında İzmir'in işgali üzerine Denizli müftüsü Ahmet Hulusi Efendi’nin verdiği fetvada şunları yazdığını aktarır: 'Korkmayınız!' ... Meyus (ümitsiz) olmayınız!... Bu livâ-yı hamd (Hz. Muhammed'in bayrağı) altında toplanınız ve mücadeleye hazırlanınız. Müftünüz olarak cihâd-1 mukaddes (kutsal cihat) fetvasını ilan ve tebliğ ediyorum”, Nurullah Çetin, “İstiklâl Marşı'mızı Anlamak”, Ankara Üniversitesi Dil Ve Tarih-Coğrafya Fakültesi Türkoloji Dergisi 21, 2 (2014) s. 44.
} 
Sevinme bir, act bir, gaye aynl, vicdan bir;

Değil mi sinede birdir vuran yürek... Yllmaz;

Cihan ylkılsa emin bu cebhe sarsılmaz!" (Safahat, s. 309-310)

Burada geçen "korkma" kelimesini tek başına almak da doğru değildir. Çünkü marşın tamamında anlatılanlar ve şairin çizdiği tabloda, kahraman Türk askeri için, sen tarihi yüce, atalarından itibaren şehit olmayı en yüce mertebe bilen, Allah'ın (Hakk) vadi olan bir milletin askerisin demektedir. Mehmet Akif, iyi bir şair olduğu kadar İslam Tarihi'ni de çok iyi bilen bir isimdir. Nitekim Hz. Peygamber yakın dostu Hz. Ebubekir'le Mekke'den Medine'ye hicret ederken, yolda sığındıkları Sevr Mağarası'nda iken peşine düşüp onları öldürmek isteyen düşmanlar, onların ayakucuna kadar gelmişlerdir. Böyle bir ortamda Allah'ın Resulüne bir şey olacağı endişesiyle çok korkan Hz. Ebubekir'e Hz. Peygamber: "Korkma! Üzülme. Allah bizimle beraberdir." ${ }^{8}$ der.

Mehmet Akif, ilk hitap ifadesinden sonra ilk iki dörtlükte seslendiği "sancak", bir milletin, ülkenin bağımsızlığını temsil eden ve uğrunda her şeyin feda edilmesinin göze alındığı bayraktır. "Sancak", "bayrak” vatanın üstünde en son ev yık1lıp yok oluncaya kadar parlamaya ve dalgalanmaya devam edecektir. Çünkü millete ait olan ve milletin bağımsızlığını simgeleyen bayrak, o millet var olduğu sürece hep yukarda olacaktır. Şairin ikinci kıtanın ve onuncu kıtanın sonunda (ki burada beşinci dize olarak) tekrar ettiği "Hakkıdır, Hakk'a tapan milletimin istiklâl” mısra1, Müslüman Türk milletinin neden "istiklal" hakkı olduğunu özetler niteliktedir. Çünkü Allah'a ve onun yardımına inanan bir milleti, yenecek, alt edecek bir güç yoktur. Şairin inancına göre de Allahüteala "istiklali” kendine güvenip dayananlara vaat etmiştir. Dolayısıyla Allah'a iman edip ibadet eden ve zahiri şartları da yerine getirenlerin bağımsızlık haklarıdır.

8 Bu hadiseye Kur'an-ı Kerim'de şöyle değinilir: "Eğer siz ona yardım etmezseniz Allah ona yardım eder. Hani o kâfirler, onu (Mekke'den) çıkardıkları vakit iki kişiden biri iken ikisi mağarada bulundukları sırada arkadaşına: "Korkma, üzülme, çünkü Allah bizimle beraberdir.” diyordu. Allah ona sekînet (sükunet, kalp huzuru) indirdi ve onu, görmediğiniz ordularla güçlendirdi ve kâfirlerin sözünü alçalttı. En yüksek olan ancak Allah'ın kelimesi (Tevhid: Lâilâhe illallah) dir ve Allah azîzdir, hakîmdir.” (Tevbe: 9/40). 
Mehmet Akif'in örnek teşkil edecek yönlerden birisi de, hak ve hakikat şairi olmasıdır. Şiirlerinde ve diğer yazılarında dile getirdiği önemli meselelerden birisidir hak ve hakikat kavramları. İstiklal Marşı'nın da ana kavramlarından birisi olan "Hak" hem bütün âlemi yaratan Allah anlamında hem de sözlüklerdeki karşılığıyla, doğru, gerçek, adaletin, hukukun gerektirdiği veya birine ayrılan kazanç vs anlamında sosyal hayattaki karşılı̆̆ıyla bir arada kullanıldığ

"Halık'ın nâ-mütenâhî adı var, en başı: Hak.

Ne büyük şey kul için hakkın elinden tutmak!" (Safahat, s. 382)

Bütün mazlumların, mağdurların temsilcisi olan "dava insanının önemli vasıflarından birisi, her şeyi göze alıp "Çiğnerim, çiğnenirim, hakkı tutar kaldırırım." (Safahat, s. 362) diyebilmesindedir.

On dokuzuncu asrın temel kavramlarından birisi medeniyettir. Batının başta fen ve teknoloji olmak üzere gelişmişliği, "terakki” edişi bu kavramla ifade edilir. İktisadi bakımdan zenginleşmiş, teknolojik yenilikleri uygulamaya geçmiş Avrupa devletlerinin bu zenginliğinin altında diğer ülke ve milletlere "medeniyet" götürme bahanesiyle sömürmesi yatmaktadır. Mehmet Akif, İstiklal Marşı’nda Batı'nın gelişmişliğine karşı Müslüman Türk milletinin imanını, inancını öne çıkarır.

"Garb'ın âfâkını sarmışsa çelik zırhlı duvar;

Benim iman dolu göğsüm gibi serhaddim var.

Ulusun, korkma! Nasıl böyle bir îmânı boğar,

"Medeniyet!" dediğin tek dişi kalmış canavar?"

Neticede tekniği kullanan da bir insandır ve sonunda inanmış insan bu tekniği alt edecektir. Çünkü medeniyetin beşiği olarak gösterilen Batı manevi olarak geride, teknik olarak ileridedir. Bu yönüyle zaten "tek dişi kalmış bir canavardır."

Mehmet Akif, Millî Mücadele'nin ilk yıllarındaki haletiruhiyeyi şöyle aktarır: "Ankara... Ya Rabbi ne heyecanlı, halecanlı günler geçirmiştik... 
Hele Bursa'nın düştüğü gün... Ya Sakarya günleri... Fakat bir gün bile ümidimizi kaybetmedik, asla ye'se (ümitsizliğe) düşmedik. Zaten başka türlü çalışabilir miydik? Ne topumuz vardı, ne tüfeğimiz... Fakat imanımız büyüktü.” (Çağbayır, 2009: 335).

Mehmet Akif daha İstiklal Marşı'nı yazmadan önce Kastamonu Nasrullah Camii'nde verdiği vaazda "Milletler topla, tüfekle, zırhlı ile, ordularla, tayyarelerle yıkılmıyor, yıkılmaz." dedikten sonra, "Benim bütün insanlar hesabına bilhassa dindaşlarım namına istediğim bir medeniyet varsa o da her manasıyla pek yüksek, namuslu, vakarlı bir medeniyettir, yani bir medeniyet-i fâzıladır. Garp medeniyeti maddiyattaki terakkisini maneviyat sahasında katiyen gösteremedi. Bilakis o ciheti büsbütün ihmal etti. Hayır, ihmal etmedi; bile bile pâymâl etti. Avrupalıların ne mal olduklarını anlayamayanlar zannederim ki bu sefer artık gözleriyle görerek hatalarını tashih etmişlerdir.” (Abdülkadiroğlu, 1992: 147, 155).

Mehmet Akif, daha gençlik yıllarından itibaren yazdığı manzum ve nesir türündeki yazılarında, verdiği vaazlarında, İstiklal Marşı'nda tecessüm eden mısraları farklı şekillerde dile getirmiştir.

İstiklal Marşı'nı özel ve ayrı kılan yönlerden birisi de kompozisyon mükemmelliğidir. Mehmet Akif, ilk iki kıtada "bağımsız ve özgür bir ülke olmanın ilk işaretlerinden birisi olan bayrağa seslenir. Marşın bundan sonraki kıtalarında kahraman Türk milletinin tarihi zenginliği, kahramanlıkları, hiç esarete girmemiş olması, Batı'nın tekniğinin iman gücünü yenemeyeceği gibi pek çok özellikleri tek tek sayar. Şair, son kıtada bağımsızlığın en önemli üç kavramı: "hilal", "bayrak" ve "istiklal"e tekrar yer verir ve nihayetinde emin bir şekilde Allah’a inanan insanların özgürlük hakkı olduğu vurgusunu bir kez daha hatırlatır.

Mehmet Akif' in çocukluğu Fatih semtinde, Fatih Camii etrafinda, caminin avlusunda ve daha küçük yaşlarda babasının yanında namazlara götürmesiyle cami içinde geçer. Küçük yaşlarda başladığı dini eğitimi camii içinde 
devam eder. Vatan toprakları tehlikeye girince halka cami kürsülerinden vaaz ederek onları birlik olmaya davet eder. Dolayısıyla Mehmet Akif için dinin önemli sembolleri ve kavramlarından olan, "ezan, mabet, camii, hudâ, şehadet, secde, vecd" vb. sıkça kullanır. Çünkü bunlar şairin hayatının birer parçalarıdır. Safahat'ın hemen başında yer alan "Fatih Camii" şiiri, İkinci Kitabın “Süleymaniye Kürsüsünde”, dördüncü kitabın "Fatih Kürsüsünde” olması, millî mücadele yolunda Balıkesir'de ve Kastamonu'da vaazlar vermesi yakın dostu Midhat Cemal Kuntay'ın ifadesiyle caminin onun hayatında ne kadar önemli yer tuttuğunu gösterir (Kutay, 2009: 210). Çünkü şair, camiyi bir mimari yapı olmanın ötesinde kendi şahsiyetiyle bütünleşen, inandıklarını ve hissettiklerini şiir halinde anlatabileceğini gösterdiği gibi, caminin cemaatiyle beraber şiire nasıl girebileceğini de en güzel şekilde örneklendirmiş olur (Yetiş, 2006: 40).

Mehmet Akif'in Millî Marş’ta geçen "hürriyet" ve "istiklal" kavramlarını da şiirlerinde kullanır. Şair doğumundan itibaren istiklale âşık biri olduğunu ifade eder. Nitekim Safahat'ın altıncı kitabı “Asım”da şöyle denilir:

"Zulmü alkışlayamam, zâlimi aslâ sevemem;

Gelenin keyfi için geçmişe kalkıp sövemem.

Biri ecdâdıma saldırdı mı, hatta boğarım...

- Boğamazsin ki!

- Hiç olmazsa yanımdan koğarım.

Üç buçuk soysuzun ardında ză̆arlık yapamam;

Hele hak nâmina haksızlı̆̆a ölsem tapamam.

Doğduğumdan beridir âşılkım istiklâle,

Bana hiç tasmalık etmiş değil altın lâle." (Safahat, s. 361)

Vatan, uğrunda her şeyin feda edileceği, gerekirse şehit oluncağı, üzerinde özgürce yaşanılan topraktır. Çünkü asırlar boyu nesiller "Hubbu'l-vatani mine'l-îmâni; Vatan sevgisi imandandır" (Yılmaz, 2013: 22) sözüyle yetişmiştir. Mehmet Akif, “Asım”da karşıllklı konuşmada, kendi kültürüne ve değerlerine yabancılaşmış ağızdan şöyle der: 
"Din, vatan, aile, millet gibi yüksek hisler.

Ahmak aldatmak için söylenilir şeylermiş..." (Safahat, s. 386)

Konuşmanın devamında şair bazı şeylere katlanmanın sebebinin de vatan uğruna olduğunu ifade eder:

"Tepeden tırnăga her gün donanıp sirsiklam.

Hani, unuttuksa o tükrükleri, faslam faslam.

Vatan uğrunda efendim, vatan uğrunda bütün." (Safahat, s. 386)

Safahat'ın “Süleymaniye Kürsüsünde"de vaaz konuşmasında vatanın içinde bulunduğu tehlikeli günleri anlatırken; "Hem vatan gitti mi, yoktur size bir başka vatan" der (Safahat, s. 165).

"Vatanın takati yoktur yeniden ihmâle:

Dolu dizgin gidiyor haksana izmihlâle!

Ey cemaat, uyanin, elverir artik uyku!

Yok mu sizlerde vatan nâmına hiçbir duygu?" (Safahat, s. 163)

Mehmet Akif, "Hakkın Sesleri”nde nesiller boyu herkese düstur olacak ilkeyi şu şekilde mısralara döker:

"Sahipsiz olan memleketin batması haktır;

Sen sâhip olursan bu vatan batmayacaktır. (Safahat s.190.)

\section{Sonuç}

Millî şairimiz Mehmet Akif, Osmanlı geleneğinin yetiştirdiği son büyük isimlerdendir. Mehmet Akif anne tarafindan Orta Asya, baba tarafindan Balkan topraklarındandır. O hayatın zorluklarıyla çocuk denecek yaşlarda karşılaşmış, çok çalışıp kendisini iyi yetiştirmiştir. Mehmet Akif, son Osman11 âlimlerinden bir babanın oğlu olarak daha çocukluğundan itibaren iyi eğitim görmüş, Kur'an'ı hıfzetmiş, Doğu dillerinden Arapça ve Farsçayı, Batı dillerinden Fransızcayı çok iyi öğrenmiş bu dillerden tercümeler yapmıştır. Mehmet Akif şair kimliği kadar fikir ve aksiyon insanı olması yönüyle de önemlidir. O, millî mücadele yıllarında Balıkesir, Kastamonu'da vaaz etmiş, 
Anadolu'nun çeşitli şehirlerini ziyaret ederek, halkı aynı duygu ve heyecan etrafında toplamaya teşvik etmiş ve bunu başarmıştır.

Mehmet Akif, başyazar olarak yer aldığı ve ilk şiirlerini yayımladığı Sıratımüstakim/Sebilürreşad onun ismiyle bütünleşmiştir. Mehmet Akif ilk şiirlerini burada yayımlamış, Osmanlı'nın içinde bulunduğu durumdan kurtulma formüllerini bu yayın organında dile getirmiştir. Mehmet Akif Osmanlı Dârülfünûn'da müderris olarak görev almış ve burada Osmanlı edebiyatı dersleri verirmiştir.

Mehmet Akif'in en çok dikkat çektiği konuların başında İslam dünyasının geri kalışının sebepleri ve eğitim, dolayısıyla "kaht-1 rical"dir. Bunun için İslam'ın esas kaynaklarından "ilham" alarak Batı medeniyetinin ortaya çıktığı teknik gelişmelerle birleştirip yeni bir model dünyaya sunmaktır. O, Batı'dan gelen zararlı fikirlere ve İslam dinine karşı yapılan kasıtlı ve haksız eleştirilere cevap vermeye, yeni teklifler getirmeye çalışır.

Mehmet Akif'in bir ahlak abidesi, vefa insanı, aksiyon adamı, iyi bir şair, iyi bir hatip, iyi bir eğitimci gibi pek çok yönünden bahsedilebilir. Ancak onu ölümsüz kılan yönlerden birisi de "Allah'ım bu millete bir daha İstiklal Marşı yazdırmasın." dediği millî marşı yazmanın da ona nasip olmasıdır. Çünkü Akif'in daha çocukluktan itibaren aldığı eğitim ve kültürel birikim, İstiklal Marşı yazılıncaya kadar, yayımlanan "Safahat”taki şiirleri onun ne kadar birikimli, kültürel derinliği olan, geleneği bilme konusunda ne kadar derin bilgiye sahip olduğunu gösterir. Mehmet Akif'in yazdığı “İstiklal Marşı" ülkenin tamamında yaşayan insanları bir bayrak altında toplayan millî bir mutabakat metnidir. Marş içinde en başta istiklal, hürriyet, bağımsızlık, bayrak, hilal, mabet, ibadet, cami, şehitlik, hak ve Hakk'a kul olmak gibi asırlar boyu değişmeyen ve özgür insan ve milletlerin ortak vasıflarını dile getiren kavramların büyük bir titizlik ve kompozisyon içinde bir araya getirildiği görülür. Bu yüzdendir ki, Mehmet Akif milletine armağan ettiği marşı, kitabına almamıştır. Türk milleti de bugüne kadar olduğu gibi cumhuriyet var olduğu sürece ilelebet devam ettirecektir. 


\section{Kaynakça}

Ayas, Nevzad (1938), "Mehmet Akif, Zihniyeti ve Düşünce Hayatı", Mehmet Akif Hayatı ve Eserleri ve 70 Muharririn Yazıları, C1, İstanbul, s. 507-580.

Ayvazoğlu, Beşir (1986), İstiklal Marşı Tarihi ve Manası, İstanbul: Tercüman Aile ve Kültür Yayınları.

Ayvazoğlu, Beşir (2006), 1924 Bir Fotoğrafin Uzun Hikâyesi, İstanbul: Kapı Yayınları.

Bilgegil, M. Kaya (1980), Yakın Çă̆ Türk Kültür ve Edebiyatı Üzerine Araştırmalar, C.2, Erzurum. Çağbayır, Yaşar (2009), Bayrak Mücadelemiz ve İstiklal Marşı, İstanbul: Ötüken Yayınevi.

Çantay, Hasan Bayri (1966), Akifnâme, İstanbul.

Çetin, Nurullah (2014), "İstiklâl Marşı'mızı Anlamak”, Ankara Üniversitesi Dil Ve Tarih-Cŏgrafya Fakültesi Türkoloji Dergisi 21, 2 (2014) 25-92.

Doğrul, Ömer Rıza (1944), “Mütefekkir Akif”, Safahat, İstanbul: İnkılap Kitabevi.

Düzdağ, M. Ertuğrul (1988), Mehmet Akif Ersoy, Ankara: Kültür ve Turizm Bakanlığı Yay.

Emil, Birol (1989), "Yunus, Fuzuli, Esrar Dede ve Avrupa Topluluğu”, Türk Edebiyatı, Kasım 1989.

Ersoy, Mehmet Akif (1988), Safahat, MÜ. İstanbul: İlahiyat Fakültesi Vakfi Yay.

Ersoy, Mehmet Akif(1992), Mehmet Akif'in Kur'an-ı Kerim 'i Tefsiri - Meviza ve Hutbeleri, hz. Abdülkadiroğlu, Abdülkerim - Abdülkadiroğlu, Ankara: Diyanet İşleri Başkanlığı Yay.

Fergan ,Eşref Edip (1938), Mehmet Akif Hayatı ve Eserleri ve 70 Muharririn Yazıları, C1, İstanbul.

Fergan, Eşref Edip (1939), Mehmet Akif Hayatı ve Eserleri ve 70 Muharririn Yazıları, C 2, İstanbul 1939.

Hazine-i Fünun, Nr. 25, 16 Kanunusani 1309/28 Aralık 1893, s.200.

İnal, İbnülemin Mahmut Kemal (1969), Son Asır Türk Şairleri, İstanbul.

Koçak, Ahmet (2021), "İslamcı Düşüncenin Ve Dergiciliğin Prototipi Olarak Sırat-1 Müstakim/ Sebilürreşad ve Hikmet Dergileri”, Sırat-1 Müstakim/Sebilürreşad Dergisi ve Mehmet Akif Ersoy, ed. Ali Kurt, Gölcük Belediyesi Yayınları, s. 105-126

Kuntay, Midhat Cemal (1938), Mehmet Akif, İstanbul.

Kuntay, Mithat Cemal (2009), Mehmet Akif Ersoy, İstanbul: Timaş Yayınları.

Mehmet Akif (1912), Tefsir-i Şerif, Sebilürreşad, II-IX/30-212, 13 Eylül 1328/26 Eylül 1912, s. 63.

Mehmet Akif (1912), Tefsir-i Şerif, Sebilürreşad, I-VIII/13-195, 17 Mayıs 1328/30 Mayıs 1912, s. 233-234.

Mehmet Akif (1912), Tefsir-i Şerif, Sebilürreşad, I-VIII/19-201, 28 Haziran 1328/11 Temmuz 1912, s. 390. 
Mertoğlu, Suat (2011), "Sıratımüstakim ve Sebilürreşad Sermuharriri Akif", Vefatının 75. Yılında Mehmet Akif Ersoy, hzl. Vahdettin Işık, İstanbul: Zeytinburnu Belediyesi Yay. s. 79-91.

Okay, M. Orhan (2001), “İstiklal Marşı”, Türkiye Diyanet Vakfi İslam Ansiklopedisi (TDV DIAA), İstanbul, C. 23, s.355-236.

Okay, M. Orhan (2011), "Mehmed Akif' in Karakteri ve Sanatı”, İstiklal Şairimiz Mehmed Akif, hz. Mustafa İsmet Uzun, Bağc1lar Belediyesi Yay. İstanbul 2011, s. 175-176.

Okay, M. Orhan (2015), Mehmed Akif Kalabalıklarda Bir Yalnız Adam, Dergâh Yay. İstanbul.

Süleyman Nazif (2016), Mehmed Akif, İstanbul: Mihrabad Yay..

Tansel, Fevziye Abdullah, Mehmet Akif, Hayatı ve Eserleri, hz. Abdullah Uçman, 4. Basım, İstanbul: Ötüken Yay.

Tansel, Fevziye Abdullah (1979), “Mehmet AkifErsoy’un Gözden Kaçan Bir Risalesi:Mebahis-i İlm-i Servet”, Kubbealtı Akademi Mecmuast, Y11:8, Nr.3, Temmuz 1979, s. 23-24.

Topçu, Nurettin, (1998), Mehmet Akif, Dergâh Yayınları.

Yetiş, Kazım (2006), Bir Mustarip: Mehmet Akif Ersoy, Ankara: Akçağ Yayınları.

Yıldırım, Tahsin (2007), Millî Mücadelede Mehmet Akif, İstanbul: Selis Kitapları.

Yılmaz, Mehmet (2013). Kültürümüzde Ayet ve Hadisler (Ansiklopedik Sözlük), İstanbul: Kesit Yay. 